\title{
KEMAMPUAN PERANGKAT DESA DALAM MENYUSUN PROFIL POTENSI DESA
}

\author{
Ability In Compiling The Village's Potential Profile
}

\author{
Asrori dan Agus Supratiawan \\ Badan Penelitian dan Pengembangan Kemendagri \\ Jln. Kramat Raya No. 132, Jakarta, tlp. (021) 3101953-55 \\ Email: asrori2011@yahoo.com \& jabreak@gmail.com \\ Diterima: 7 Maret 2014; direvisi: 16 Agustus 2014; disetujui:12 Desember 2014
}

\begin{abstract}
Abstrak
Tujuan penelitian adalah untuk mengidentifikasi penyebab data-data potensi desa kurang akurat dan aktual; untuk mengidentifikasi kemampuan Perangkat Desa dalam melakukan pendataan dan penyusunan potensi desa; dan untuk menganalisis upaya-upaya yang harus dilakukan untuk meningkatkan kemampuan Perangkat Desa dalam melakukan pendataan dan penyusunan potensi desa. Penelitian ini bersifat deskriptif analisis dengan pendekatan kualitatif. Pengisian data-data potensi/profil desa belum akurat dan tidak aktual, karena dalam pengisian profil desa belum sepenuhnya menggunakan sumber data dan prosedur yang benar. Tingkat kemampuan Perangkat Desa dalam mengisi potensi/profil desa di desa sampel belum memadai, karena yang mengerjakan hanya 1 orang dan tidak dibekali dengan Diklat pengumpulan data dan penyusunan profil desa; dan pengisian potensi/profil desa bukan menjadi tugas dan fungsi utama. Pemerintah Pusat dan Daerah kurang memperhatikan kemampuan Perangkat Desa dalam melakukan pendataan profil desa. Perlunya kebijakan standar penggunaan sumber data dalam pengisian profil desa. Kebijakan pengisian potensi/profil desa oleh tenaga pembantu teknis lapangan yang dibekali dengan diklat dan pengumpalan data potensi/profil desa. Perlunya evaluasi implementasi pengisian profil desa untuk menyederhanakan format Lampiran II dan Lampiran III Peraturan Menteri Dalam Negeri Nomor 12 Tahun 2007.

Kata kunci: kemampuan, Perangkat Desa, potensi desa.
\end{abstract}

\begin{abstract}
The aims of this research are to identify those unaccurated data. Moreover, to identify the capabilities of village government stafs when they colect village resources data; and also to analise what efforts to conduct for improving village government staffs. Describtive analised with kuantitative approach are used in this research. Potential data filing and village profile are not accurately caused by incorrect data wrong procedure. Furthermore, village government staffs in these samples are not capable to collect and to fill data. Infact, to conduct that jobs, there only one person does it and hel she have not been trained yet. National, regional governments do not have regard to the people who collecting village resource data for preparing village profile. Rules of the games are needed to make standard product. Filling village potential resource and village profile are conducted by technical field assistant who have been educated and trained to collect those data. Finally, evaluations are needed to simplify format in appendix II and III Home affair minister rules 12 Tahun 2007 (Peraturan Menteri Dalam Negeri Nomor 12 Tahun 2007)

Keywords: capability, village government staf, village resources.
\end{abstract}

\section{PENDAHULUAN}

Potensi desa merupakan keseluruhan sumber daya yang dimiliki atau digunakan oleh desa, baik sumber daya manusia, sumber daya alam, dan kelembagaan maupun prasarana dan sarana untuk mendukung percepatan kesejahteraan masyarakat.

Pendataan potensi desa tidak hanya ditujukan untuk menghasilkan data spesifik bagi keperluan pembangunan wilayah (desa), tetapi juga dimaksudkan untuk memberikan indikasi awal tentang fakta-fakta potensi wilayah, infrastruktur/ fasilitas serta kondisi sosial ekonomi dan budaya di setiap desa/kelurahan.

Secara umum tujuan pelaksanaan pendataan potensi desa adalah: 1) Menyediakan data tentang keberadaan dan perkembangan potensi yang dimiliki desa/kelurahan yang meliputi: sosial, ekonomi, sarana, dan prasarana wilayah; 2) Menyediakan data untuk berbagai keperluan yang berkaitan dengan perencanaan wilayah di tingkat nasional dan tingkat daerah; 3) Melengkapi penyusunan kerangka sampling untuk kegiatan statistik lain lebih lanjut; 4) Menyediakan data bagi keperluan penentuan klasifikasi/tipologi desa, desa tertinggal dan tidak tertinggal, dan sebagainya; dan 5) Menyediakan data pokok bagi penyusunan statistik wilayah kecil.

Melihat pentingnya data potensi desa dalam pembangunan, dalam faktanya ketersediaan datadata potensi desa tidak lengkap, bahkan tidak pernah diperbaharui setiap tahunnya. Berdasarkan hasil orientasi dalam beberapa penelitian, data-data potensi desa yang yang tertuang dalam profil desa mayoritas tidak akurat dan aktual. Akurat dan aktualnya data-data potensi desa yang yang tertuang dalam profil desa tidak terlepas dari kemampuan Perangkat Desa dalam mendata potensi desa. 


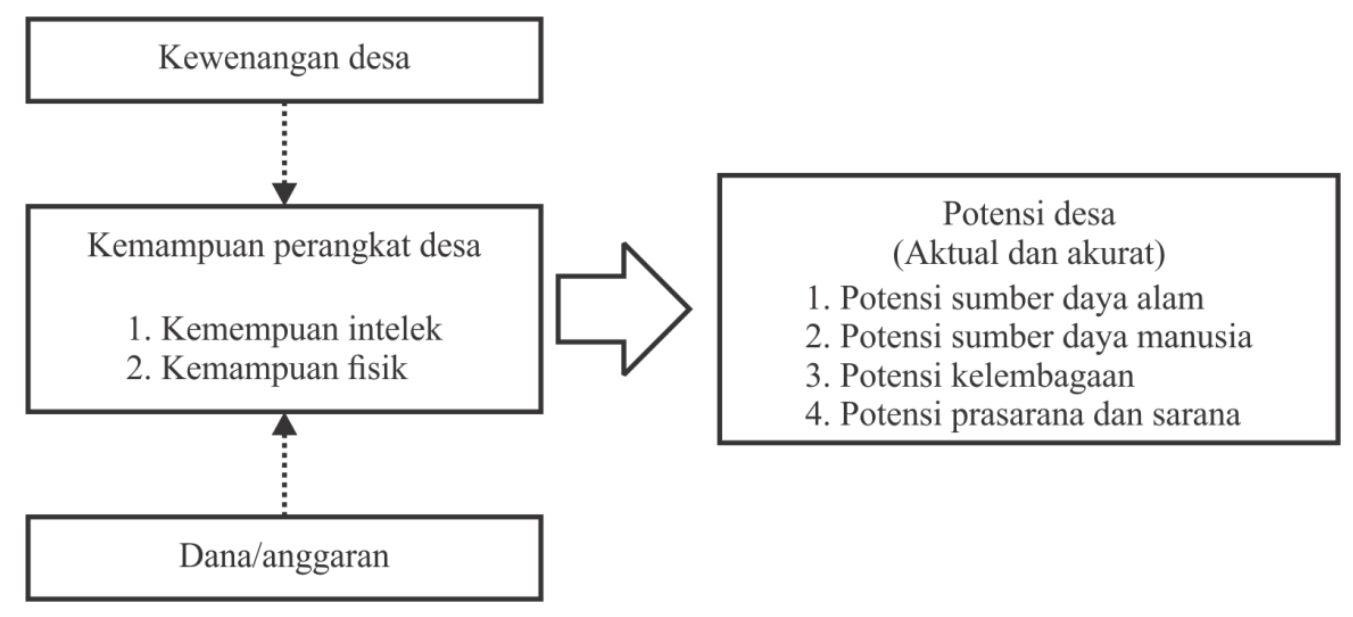

Gambar 1. Kerangka pemikiran

Kondisi saat ini menunjukkan bahwa Perangkat Desa yang ada sangat jauh dari apa yang diharapkan. Potret Perangkat Desa saat ini yang menunjukkan profesionalisme rendah, kurang kreatif dan inovatif, serta masih banyak potret negatif lainnya yang intinya menunjukkan bahwa Perangkat Desa di Indonesia masih lemah. Selain Sekretaris Desa yang saat ini diangkat menjadi PNS, status Perangkat Desa sebagai alat kelengkapan pemerintahan desa yang bertanggung jawab melaksanakan roda pemerintahan desa sehari-hari masih lemah, karena profesi Perangkat Desa pada umumnya masih diidentikkan dengan pengabdian yang bersifat sosial. Sistem pola karir, penggajian, promosi, pemberhentian dan sebagainya tidak berlaku dalam pembinaan Perangkat Desa. Dalam rekrutmen Perangkat Desa, pendidikan tidak menjadi indikator utama, tetapi ketokohan dan tidak ada batasan usia purna tugas yang jelas.

Secara kualitas, Perangkat Desa saat ini relative masih rendah, dilihat dari tingkat pendidikan mayoritas tamat SD, bahkan banyak yang tidak lulus SD. Kondisi ini hampir dijumpai di setiap daerah baik desa-desa di Pulau Jawa mapun luar Pulau Jawa, terlebih daerah seperti Papua, mayoritas yang memduduki perangkat kampung (desa) berpendidikan tidak tamat SD. Di samping kualitas, secara kuantitas Perangkat Desa juga relatif masih rendah. Jumlah Perangkat Desa di Jawa dan Bali pada umumnya tidak sebanding dengan jumlah penduduk, sedangkan jumlah Perangkat Desa di luar Jawa dan Bali tidak sebanding dengan luas wilayahnya.

Keterbatasan Perangkat Desa baik secara kualitas maupun kuantitas sangat berpengaruh terhadap kemampuan Perangkat Desa dalam menjalankan tugas roda pemerintahan desa. Salah satu tugas Perangkat Desa adalah pendataan dan penyusunan potensi desa. Tugas pendataan dan penyusunan potensi desa merupakan tugas yang memerlukan pengetahuan dan ketrampilan tersendiri dari Perangkat Desa. Sedangkan dilihat dari kemampuan Perangkat Desa yang secara umum relatif masih rendah, serta belum adanya dukungan dana dalam APBDes yang dialokasikan untuk pendataan dan penyusunan potensi desa, maka tidak mengherankan kalau ketersediaaan data-data potensi desa yang dihimpun Perangkat Desa dalam profil desa tidak akurat dan aktual.

Pokok Permasalahan dalam penelitian ini adalah:

1. Apa yang menyebabkan data-data potensi desa kurang akurat dan aktual?

2. Bagaimana kemampuan Perangkat Desa dalam melakukan pendataan dan penyusunan potensi desa?

3. Upaya-upaya apa saja yang harus dilakukan untuk meningkatkan kemampuan Perangkat Desa dalam melakukan pendataan dan penyusunan potensi desa?

Tujuan penelitian adalah untuk: mengidentifikasi penyebab data-data potensi desa kurang akurat dan aktual; mengidentifikasi kemampuan Perangkat Desa dalam melakukan pendataan dan penyusunan potensi desa; dan menganalisis upaya-upaya meningkatkan kemampuan Perangkat Desa.

Potensi desa adalah kemampuan yang dapat dikembangkan dalam pembangunan suatu desa. Potensi desa mencakup keadaan alam dan manusia yang ada di dalamnya beserta hasil-hasil kerja manusianya. Potensi suatu desa terdiri atas komponen alam dan komponen manusia. Program pembangunan desa merupakan salah satu usaha pemerintah dalam meningkatkan taraf hidap dan kesehjateraan masyarakat di lingkungan pedesaan.

Berdasarkan Lampiran II dan Lampiran III Peraturan Menteri Dalam Negeri Nomor 12 tahun 2007 tentang Pedoman Penyusunan dan Pendayagunaan Data Profil Desa dan Kelurahan, dimana data profil desa terdiri dari:

1. Potensi Sumber Daya Alam

2. Potensi Sumber Daya Manusia

3. Potensi Kelembagaan 
4. Potensi Prasarana dan Sarana.

Pemerintahan desa merupakan penyelenggaraan urusan pemerintahan oleh Pemerintah Desa dan Badan Permusyawaratan Desa dalam mengatur dan mengurus kepentingan masyarakat setempat berdasarkan asal-usul dan adat istiadat setempat yang diakui dan dihormati dalam sistem Pemerintahan Negara Kesatuan Republik Indonesia (NKRI). Urusan pemerintahan yang menjadi kewenangan desa mencakup urusan pemerintahan yang sudah ada berdasarkan hak asal-usul desa, urusan pemerintahan yang menjadi kewenangan kabupaten/kota yang diserahkan pengaturannya kepada desa, tugas pembantuan dari pemerintah dan pemerintah daerah, urusan pemerintah lainnya yang oleh peraturan perundangan-undangan yang diserahkan kepada desa.

Pemerintah desa merupakan unit terdepan dan berhadapan langsung dalam pelayanan pemerintahan dan pemberdayaan masyarakat, serta menjadi tonggak utama untuk keberhasilan semua program pemerintah. Memperkuat desa merupakan suatu upaya untuk mempercepat terwujudnya kesejahteraan masyarakat. Dalam upaya meningkatkan kapasitas pelayanan kepada masyarakat, selain mendudukkan desa menurut urusan pemeriantahan yang menjadi kewenangan desa, kepastian tersedianya pendanaan untuk menyelenggarakan pemerintahan dan pemberdayaan masyarakat serta tersedianya SDM yang mampu menyelenggarakan pelayanan kepada masyarakat.

Pemerintah Desa atau yang disebut dengan nama lain adalah Kepala Desa dan Perangkat Desa sebagai unsur penyelenggara pemerintahan desa. Perangkat Desa terdiri dari Sekretaris Desa dan Perangkat Desa lainnya. Perangkat Desa bertugas membantu Kepala Desa dalam melaksanakan tugas dan wewenangnya. Perangkat Desa bertanggung jawab kepada Kepala Desa

Saat ini, kewenangan yang dimiliki desa untuk mengurus urusan rumah tangga desa diatur dalam Undang-Undang No 32 Tahun 2004 Pasal 2006. Adapun kewenangan dimaksud adalah:

1. Urusan pemerintahan yang sudah ada berdasarkan hak asal-usul desa.

2. Urusan pemerintahan yang menjadi kewenangan kabupaten/kota yang diserahkan pengaturannya kepada desa.

3. Tugas pembantuan dari Pemerintah, Pemerintah Provinsi, dan/atau Pemerintah Kabupaten/Kota.

4. Urusan pemerintahan lainnya yang oleh peraturan perundang-perundangan diserahkan kepada desa.

Selanjutnya menurut Peraturan Pemerintah Republik Indonesia No. 72 Tahun 2005 tentang Desa pada Pasal 14 ayat 1 dan 2, menyebutkan Kepala Desa mempunyai tugas menyelenggarakan urusan pemerintahan, pembangunan, dan kemasyarakatan.
Dalam Permandagri Nomor 30 Tahun 2006 Pasal 2 menyebutkan bahwa urusan pemerintahan Kabupaten/Kota yang dapat diserahkan pengaturannya kepada Desa antara lain bidang otonomi desa yang diantaranya urusan penelitian dan pendataan potensi desa.

Dalam "otonomi desa", pembiayaan, penyelenggaraan urusan rumah tangga desa berasal dari Anggaran Pendapatan dan Belanja Desa (APBDes), dan bantuan Pemerintah dan Pemerintah Daerah. Penyelenggaraan urusan pemerintahan Kabupaten/Kota yang diserahkan pengaturannya ke desa didanai dari APBD dan begitupun dengan pendanaan urusan pemerintahan lainnya (tugas pembantuan) yang diselenggarakan oleh pemerintah desa berasal dari yang memberikan tugas (Pemerintah, Provinsi atau Kabupaten/Kota).

Manajemen pengembangan SDM dapat dilihat dari dua aspek, yaitu aspek kuantitas dan aspek kualitas. Aspek kuantitas menyangkut jumlah SDM (penduduk), sedangkan aspek kualitas menyangkut mutu SDM, yaitu kualitas fisik maupun kualitas non fisik (kecerdasan dan mental). Untuk meningkatkan kualitas fisik dapat dilakukan melalui program peningkatan kesehatan dan gizi, sedangkan untuk meningkatkan kualitas kecerdasan dan mental diupayakan dengan pendidikan dan pelatihan.

Secara makro, pengembangan SDM, diartikan sebagai proses peningkatan kualitas atau kemampuan manusia dalam rangka mencapai tujuan pembangunan. Proses peningkatan ini mencakup perencanaan, pengembangan dan pengelolaan SDM. Secara mikro, pengertian SDM dalam lingkungan unit kerja (organisasi atau lembaga) yang dimaksud adalah tenaga kerja, pegawai. Berdasarkan itu, pengembangan SDM secara mikro adalah proses perencanaan pendidikan, pelatihan dan pengelolaan pegawai/karyawan untuk mencapai hasil yang optimal. Proses pengembangan SDM terdiri dari perencanaan, pendidikan dan pelatihan dan pengelolaan (Notoatmodjo, 1998; 2-3).

Kemampuan merupakan kapasitas seseorang individu untuk mengerjakan berbagai tugas dalam suatu pekerjaan. Kemampuan intelektual adalah kemampuan untuk mengerjakan kegiatan mental, sedangkan kemampuan fisik adalah kemampuan untuk melakukan tugas-tugas yang menuntut stamina, kecakapan, kekuatan dan ketrampilan (Gibson, 1994: 55).

Kemampuan yang berhubungan dengan tugas dan pekerjaan adalah kesanggupan seseorang dalam melaksanakan pekerjaan secara sunguh-sungguh dan memberikan hasil yag baik. Kemampuan merupakan keterampilan, pengetahuan, dan mental bekerja seseorang yang didukung dengan kondisi fisik yang baik. Berdasarkan kondisi ini, unsur utama kemampuan Perangkat Desa adalah pengetahuan dan ketrampilan yang diperoleh dari 
pendidikan, keterampilan, atau pengalaman selama bekerja yang didukung dengan mental dan kondisi fisik yang baik.

Untuk meningkatkan kemampuan seseorang pegawai dapat dilakukan melalui pendidikan dan pelatihan. Pendidikan membentuk dan menambah pengetahuan tentang sesuatu dengan lebih cepat dan tepat. Sedangkan pelatihan akan membentuk keterampilan kerja (Simanjuntak, 1982; 144). Nawawi (2000; 67) berpendapat "peningkatan kemampuan dan kemahiran kerja dapat ditempuh dengan jalan menambah pengetahuan dan latihanlatihan bagi para personil melalui penataran, tugas belajar, latihan kerja di lingkungan sendiri atau di lingkungan lain dan di dalam atau di luar negeri”.

\section{METODE PENELITIAN}

Kemampuan Perangkat Desa dalam penyusunan potensi desa ini merupakan studi kasus di Desa Getassrabi, Kecamatan Gebog, Kabupaten Kudus. Penelitian ini bersifat deskriptif analisis dengan pendekatan kualitatif. Dalam studi ini data kumpulkan dengan teknik: penelusuran dokumentasi, wawancara dan pengamatan lapangan. Teknik analisis data dilakukan dengan menggunakan analisis interpretatif menggambarkan data yang ditemukan sesuai dengan rumusan masalah.

\section{HASIL DAN PEMBAHASAN}

\section{a. Akurasi dan Aktualisasi Data-Data Potensi Desa \\ Desa Getassrabi memiliki data profil desa} dalam bentuk buku dan papan tulis. Untuk data desa yang ditulis pada papan tulis merupakan monografi desa, format monografi desa masih menggunakan format lama dan sampai sekarang belum disesuaikan dengan format yang baru. Data-data di papan tulis adalah data-data tahun 2005 yang belum disesuaikan dengan perkembangan data yang baru. Sedangkan buku data profil desa merupakan hasil isian format data profil desa (Lampiran II dan Lampiran III Peraturan Menteri Dalam Negeri Nomor 12 Tahun 2007), yang diperoleh dari Bagian Pemerintahan Desa Sekretaris Daerah Kabupaten Kudus sampai dengan Tahun 2009, dan mulai tahun 2010 diperoleh dari Badan Pemberdayaan Masyarakat, Perempuan dan Keluarga Berencana (BPMPKB). Pengisian profil Desa Getassrabi yang mengacu pada Lampiran II dan Lampiran III Peraturan Menteri Dalam Negeri Nomor 12 Tahun 2007, dimulai pada pengisian profil desa tahun 2010.

Menurut informan Mulyono sebagai (Kepala Urusan Pembangunan) dalam pengalamannya selama 23 tahun sebagai penanggung jawab pengisian monografi desa, potensi desa maupun profil desa yang, dalam pengisian data, agar data yang diperoleh akurat dan aktual sumber data seharusnya berasal dari: kecamatan, PLKB, BPS, desa, dusun/RW/RT, bidan desa, dan masyarakat. Namun demikian hal tersebut belum sepenuhnya dilakukan. Dalam pengisian data monografi desa, potensi desa maupun profil desa yang dilakukan selama ini cenderung berdasarkan perkiraan dan data tahun sebelumnya, khususnya data-data yang terkait dengan peternakan, pertanian tanaman pangan, buah-buahan, air bersih, dan mata pencaharian.

Format data potensi/profil desa menurut informan (Mulyono, Kaur. Pembangunan Desa Getassrabi) selalu berubah, khususnya terkait dengan data penduduk, misalnya klasifikasi umur. Hal ini menyulitkan dalam pengisian data. Di samping itu format daftar isian profil desa (Lampiran II dan Lampiran III Peraturan Menteri Dalam Negeri Nomor 12 Tahun 2007) dianggap rumit dan mengalami kesulitan untuk mengisi, untuk itu format profil desa disederhanakan.

Selama ini Pemerintah Kabupaten Kudus maupun Kecamatan Gebog, belum pernah mengeluarkan aturan terkait dengan data potensi desa/data profil desa. Pemda hanya memberikan pedoman pendataan dan pendayagunaan profil desa dan kelurahan. Pedomanan yang diberikan adalah dalam Lampiran II dan Lampiran III Peraturan Menteri Dalam Negeri Nomor 12 tahun 2007, namun dekikian pemerintah desa berkewajiban untuk mengisi data profil desa setiap tahun dan harus diserahkan paling lambat 3 bulan sebelum tahun anggaran baru. Setiap tahun desa selalu mendapat paket berkas/buku data profil desa rangkap tiga yang harus diisi, dimana 1 berkas data profil desa untuk BPMKB, 1 berkas data profil desa untuk kecamatan dan 1 berkas data profil desa untuk arsif desa. Sedangkan data profil desa yang terakhir diisi adalah tahun 2010. Khusus data kependudukan, ditingkat desa selalu dilakukan pembaharuan data setiap minggu, dan dilaporkan ke kecamatan setiap bulan. Data kependudukan di desa selalu diperbaharui, karena perubahan data penduduk sangat tinggi, tetapi data kependudukan yang dibuat desa tidak singkron dengan data kependudukan yang dikeluarkan oleh Dinas Catatan Sipil, dimana selisihnya sangat signifikan, yaitu mencapai 2.000 jiwa, dimana berdasarkan data 2010 adalah 10.571 orang, sedangkan data kependudukan yang dikeluarkan oleh Dinas Catatan Sipil lebih dari 12.500 orang. Namun demikian data mana yang valid dan akurat, tidak diketahui secara pasti karena terdapat perbedaan metode pendataan. Pendataan kependudukan desa yang dilakukan berdasarkan dari data pemutakhiran kartu keluarga dan hasil pemutakhiran administrasi kependudukan berdasarkan warga yang mengurus administrasi kependudukan di desa.

Untuk mengetahui bagaimana akurasi data kependudukan, dapat dibandingkan data kependudukan Desa Getassrabi Tahun 2007, 2008, dan tahun 2009 sebagai data profil desa dengan format lama dengan data tahun 2010 sebagai data 
profil desa dengan format baru (Lampiran II dan Lampiran III Peraturan Menteri Dalam Negeri Nomor 12 Tahun 2007).

\begin{tabular}{cccc}
\hline 2007 & 2008 & 2009 & 2010 \\
\hline 10.464 & 10.466 & 10.464 & 10.571 \\
\hline
\end{tabular}

Sumber: Data Skunder diolah.

Dari data kependudukan sebagaimana tabel tersebut diatas diketahui, bahwa jumlah penduduk dari tahun 2007 s/d 2009 hampir sama, sedangkan untuk tahun 2010 terjadi penambahan yang signifikan. Dalam data tahun 2007 s/d 2009 masih menggunakan format lama, sehingga dalam pengisian cenderung menggunakan data tahun sebelumnya. Sedangkan tahun 2010 yang sudah menggunakan format baru, datanya terjadi kenaikan 107 orang dibandingkan data tahun 2009. Terjadinya kenaikan yang relatif besar tersebut dibanding tahuntahun sebelumnya, setelah dikonfirmasi dengan informan, apakah tahun 2010 terjadi kelahiran yang lebih tinggi atau adanya pendatang yang lebih besar dari tahun 2007 s/d 2009 atau pada tahun 2007 s/d 2009 tingkat kematian lebih tinggi dibandingkan dengan tingkat kelahiran, atau terjadi migrasi keluar desa. Dari hasil konfirmasi diketahui bahwa antara tahun 2007 s/d tahun 2010 tidak ada kejadian yang ekstrim dalam pertumbuhan penduduk di Desa Getassrabi. Sedagkan saat dikorfirmasi mengenai perkembangan penduduk antara tahun 2007 s/d 2009 dan perkembangan penduduk antara tahun 2009 tahun 2010, terjadi perbedaan yang cukup signifikan, maka Kaur Pembangunan sebagai penanggung jawab untuk mengisi data profil desa diketahui bahwa, yang bersangkutan sendiri meragukan kebenaran data tersebut, karena dalam pengisian data kadang-kadang terburu-buru disebabkan keterbatasan waktu, sehingga data disamakan dengan tahun sebelumnya, atau diperkirakan. Sedangkan untuk data tahun 2010, memang berdasarkan hasil rekap data kependudukan yang dilaporkan ke kecamatan secara periodik.

Data profil desa sebagaimana dituangkan dalam Lampiran II dan Lampiran III Peraturan Menteri Dalam Negeri Nomor 12 tahun 2007, dimana data profil desa terdiri dari (1) Potensi Sumber Daya Alam; (2) Potensi Sumber Daya Manusia; (3) Potensi Kelembagaan; dan (4) Potensi Prasarana dan Sarana. Untuk mengetahui kelengkapan data profil Desa Getassrabi adalah sebagai berikut:

1. Potensi Sumber Daya Alam. Kelengkapan data-data potensi sumber daya alam yang tertuang dalam profil Desa Getassrabi mayoritas sudah terisi cukup baik, tetapi belum akurat dan tidak aktual, karena data-data tidak diperoleh dari hasil pendataan lapangan, tetapi berdasarkan perkiraan dan data tahun sebelumnya.
2. Potensi Sumber Daya Manusia. Kelengkapan data-data potensi sumber daya manusia yang tertuang dalam profil Desa mayoritas sudah terisi cukup baik, tetapi belum akurat dan tidak aktual, karena data-data tidak diperoleh dari hasil pendataan lapangan, tetapi berdasarkan perkiraan dan data tahun sebelumnya.

3. Potensi Kelembagaan. Kelengkapan data-data potensi kelembagaan yang tertuang dalam profil Desa mayoritas sudah terisi cukup baik, tetapi akurasi dan aktualisasi data masih diragukan, karena data-data tidak diperoleh dari hasil pendataan lapangan, tetapi berdasarkan perkiraan dan data tahun sebelumnya.

4. Prasarana dan Sarana. Kelengkapan data-data potensi sarana dan prasarana desa yang tertuang dalam profil Desa Getassrabi mayoritas sudah terisi cukup baik, akurat dan aktual, karena data-data diperoleh dari hasil pendataan dan pengamatan lapangan.

Kendala yang dihadapi dalam melakukan pendataan potensi desa/profil desa yang teridentifikasi adalah: 1) Kepala Dusun dan Ketua RT selama ini belum melakukan pendataan/ menginventalisir sumber daya desa; 2) sulitnya mendapat data dari masyarakat karena tingkat kesadaran/partisipasi masyarakat untuk melaporkan data-data bila terjadi perubahan masih rendah; 3) adanya keengganan Kepala Dusun dan Ketua RT untuk melakukan pendataan kepada masyarakat, karena adanya image dari masyarakat kalau ada pendataan selalu dikaitkan akan mendapat bantuan, sehingga Kepala Dusun dan Ketua RT takut nantinya ditagih bantuannya; 4) tidak tersedianya dana untuk melakukan pengumpulan data; 5) terbatasnya sarana untuk melakukan pendataan; 6) data-data BPS justru diperoleh dari Perangkat Desa.

Sumber daya desa yang terinventalisir dalam profil desa dengan tujuan untuk memperoleh gambaran menyeluruh tentang karakter desa yang meliputi data dasar keluarga, potensi sumber daya alam, sumber daya manusia, kelembagaan dan sarana serta perkembangan kemajuan dan permasalahan yang dihadapi desa sebagaimana dituangkan dalam Lampiran II dan Lampiran III Peraturan Menteri Dalam Negeri Nomor 12 tahun 2007 dibagi dalam 1) Potensi Sumber Daya Alam; 2) Potensi Sumber Daya Manusia; 3) Potensi Kelembagaan; dan 4) Potensi Prasarana dan Sarana, di Desa Getassrabi dilihat dari isian data, mayoritas sudah terisi cukup baik, tetapi dilihat dari akurasi dan aktualitas data masih kurang, karena pengisian data belum mengacu aturan yang ada, yaitu melakukian pendataan dengan sumber dari BPS, Kecamatan, Kepala Dusun/RW, PLKB, Bidan Desa, Ketua RT dan masyarakat. Sedangkan dalam pengisian data profil desa hanya menggunakan perkiraan dan data tahun seblumnya. Rendahnya 
akurasi dan aktualitas data profil desa dibenarkan oleh semua informan dilapangan.

\section{b. Kemampuan Perangkat Desa dalam Melakukan Pendataan Dan Penyusunan Potensi Desa}

Secara formal belum ada urusan yang diserahkan kepada desa untuk mengurus dan mengatur urusan penelitian dan pendataan potensi desa, dimana penelitian dan pendataan potensi desa merupakan salah satu bagian urusan dibidang otonomi desa yang menjadi urusan pemerintah kabupaten yang dapat diserahkan kepada pemerintah desa sebagaimana diatur dalam Permendagri Nomor 30 Tahun 2006, tentang Tatacara Penyerahan Urusan Pemerintahan Kabupaten/Kota Kepada Desa. Belum adanya penyerahan urusan tidak hanya urusan untuk mengurus dan mengatur urusan penelitian dan pendataan potensi desa saja, tetapi seluruh urusan pemerintah Kabupaten yang dapat diserahkan kepada pemerintah desa belum ada yang diserahkan kepada desa, karena sampai saat ini belum ada Perda, yang menindaklanjuti Permendagri Nomor 30 Tahun 2006 untuk mengatur penyerahan urusan pemerintah Kabupaten Kudus kepada pemerintah desa. Sedangkan selama ini desa hanya mendapat isian profil desa (Lampiran Permandagri Nomor 12 Tahun 2007) dari Bagian Pemerintahan Desa Sekretaris Daerah dan mendapat pengarahan dari kecamatan untuk segera mengisi.

Belum adanya penyerahan urusan pemerintah kabupaten kepada pemerintahan desa khususnya urusan penelitian dan pendataan potensi desa jelas mempengaruhi kemampuan Perangkat Desa dalam melakukan pendataan, penyusunan dan pengisian profil desa. Perangkan desa tidak akan maksimal dalam melakukan pendataan, penyusunan dan pengisian profil desa karena desa tidak memiliki urusan dan menganggap tugas tersebut menjadi tanggung jawab pemerintah kabupaten.

Penanggung jawab dalam penyusunan data potensi/profil desa adalah kaur Pembangunan, walaupun tugas penyusunan data potensi/profil desa tidak termasuk dalam tugas dan Kaur Pembangunan. Dalam hal ini Kaur Pembangunan sebagai penanggungjawab dalam penyusunan data potensi/profil desa tidak dibantu oleh Perangkat Desa yang lain. Dengan melihat dalam pelaksanaan pendataan dan pengisian potensi desa yang hanya dilakukan oleh Kaur Pembangunan dengan tingkat pendidikan rata-rata SMP walaupun memiliki masa kerja yang relatif lama, tanpa dibantu oleh Perangkat Desa lainnya serta masih dibebani dengan berbagai tugas sesuai dengan fungsinya, maka kemampuan untuk melakukan pendataan dan penyusunan potensi desa menjadi kurang memadai.

Disamping tingkat pendidikan yang kurang memadai untuk melakukan pendataan dan penyusunan potensi desa, Kaur Pembangunan maupun Perangkat Desa lainnya selama ini belum pernah mendapat pelatihan/penataran/studi banding yang terkait dengan pengisian dan penyusunan datadata potensi desa/profil desa. Selama ini Kaur Pembangunan hanya diberi pengarahan dari Bagian Pemeriantahan Desa Sekretaris Daerah maupun Kasi dari kecamatan, agar Pemerintah Desa untuk segera mengisi dan menyerahkan profil desa sesuai batas waktu yang ditentukan.

Sebagaimana telah disinggung diatas, bahwa yang melaksanakan penyusunan data-data potensi desa/profil desa hanya Kaur Pembangunan tanpa keterlibatan Perangkat Desa, dikarenakan tugas penyusunan data-data potensi desa/profil lebih mendekati dengan tugas dan fungsi Kaur Pembangunan. Berdasarkan pengalaman Kaur Pembangunan dalam menangani pengisian monografi desa, potensi desa dan profil desa, serta menggambar peta desa, dalam melaksanakan kegiatan pengisian tersebut pernah melakukan pengamatan dan keliling desa dan menanyakan Kepala Dusun terkait dengan data-data kependudukan dan rumah tangga. Namun demikian kegiatan tersebut tidak selalu dilakukan, mengingat banyaknya beban tugas yang harus diselesaikan dalam pelayanan masyarakat.

Mengingat pengisian profil desa yang diterima dari kecamatan harus terisi dalam jangka waktu kurang lebih 3 bulan, maka dalam melakukan pengisian data profil desa yang dilakukan selama ini tidak selalu berdasarkan pada data-data lapangan, tetapi berdasarkan perkiraan dengan melihat datadata tahun sebelumnya, sedangkan data-data terkait dengan pertanian didapat dari kecamatan, bukannya dari Kepala Dusun ataupun RT.

Dari 60 jenis data yang harus diisi, 15 jenis mengalami kesulitan, sedangkan 45 jenis data tidak mengalami kesulitan. Dilihat dari kualitas, walaupun 15 jenis data dalam pengisian mengalami kesulitan, tetapi data tersebut merupakan data yang sangat penting, seperti data pertanian tanaman pangan, peternakan, tanaman obat, dan data-data kependudukan. Sedangkan 45 jenis data yang dalam pengisiannya tidak mengalami kesulitan disebabkan mayoritas data yang dibutuhkan memang tidak ada di desa (tidak memiliki potensi), seperti data potensi umum, kehutanan, bahan galian sumber daya air, perikanan, wisata dan data-data prasarana dan sarana.

Dilihat dari tingkat kesulitan Perangkat Desa dalam hal ini Kaur Pembangunan dalam melakukan pengisian data-data profil desa disebabkan karena adanya pergantian isian format profil desa (yang terbaru mengacu pada lampiran II dan III Peraturan Menteri Dalam Negeri Nomor 12 tahun 2007); terbatasnya tenaga yang melakukan pengisian dan pendataan profil desa (hanya Kaur Pembangunan); terbatasnya pengatahuan baik dilihat dari pendidikan formal, yang hanya lulus SMP dan tidak pernah mendapat pelatihan pengisian profil desa; tidak tersedianya dana yang memadai untuk melakukan 
penelitian dan pendataan profil desa, tidak dilibatkannya Kepala Dusun dan Ketua RT dalam pengumpulan data profil desa karena tidak adanya dana.

Kemampuan yang berhubungan dengan tugas dan pekerjaan yaitu kesanggupan seseorang dalam melaksanakan pekerjaan secara sunguh-sungguh dan memberikan hasil yag baik. Kemampuan merupakan keterampilan, pengetahuan, dan mental bekerja seseorang yang didukung dengan kondisi fisik yang baik. Dilihat dari pengetahuan dan ketrampilan, pengalaman bekerja, mental dan kondisi fisik, maka kemampuan Kaur Pembangunan Desa Getassrabi sebagai Perangkat Desa yang bertanggungjawab atas pengisian profil desa belum sepenuhnya memiliki kemampuan untuk melaksanakan beban tugas dan pekerjaan, walaupun dilihat dari segi pengalaman (23 tahun menjabat Kaur Pembangunan), usia (56 tahun), dan semangat untuk mengabdi masih memadai, tetapi dilihat dari segi pendidikan (lulus SMP) tanpa dibekali dengan diklat pengumpulan data dan penyusunan profil desa yang baik dan benar serta masih dituntut dengan beban tugas utama sebagai kaur pembangunan maka tingkat kemampuannya untuk dapat menyelesaikan tugas masih belum memadai.

Dari kondisi tersebut memperlihatkan bahwa 1) Perangkat Desa yang tersedia belum dipergunakan secara berdaya guna dan berhasil guna, karena hanya dilakukan oleh kaur pembangunan, sedangkan kaur lainnya maupun Kadus belum didayagunakan 2) hubungan kerja yang menyenangkan dan produktifitas dalam kerangka mencapai tujuan belum diciptakan oleh kepala desa, karena hanya mengandalkan kaur pembangunan; dan 3) semua Perangkat Desa belum ditingkatkan perkembangannya sampai batas kemampuan maksimal masingmasing dan sesuai pula dengan perkembangan cara dan peralatan yang memadai.

\section{c. Upaya-Upaya Peningkatkan Kemampuan Perangkat Desa dalam Melakukan Pendataan dan Penyusunan Potensi Desa}

1. Pemerintah Kabupaten/Desa belum memfasilitasi Perangkat Desa untuk meningkatkan pendidikan formal, seperti tugas belajar, kursus, ijin belajar. Tetapi bila ada Perangkat Desa yang berinisiatif untuk melanjutkan pendidikan dengan biaya sendiri dipersilahkan. Sedangkan Pemerintah Kabupaten/Desa tidak sanggup untuk memberi batuan biaya.

2. Pemerintah Provinsi, Kabupaten maupun Desa belum pernah memfasilitasi Perangkat Desa untuk mengikuti pelatihan/penataran mengenai cara-cara survei/pendataan potensi desa/profil desa (seperti teknik pengamatan, wawancara, dan pencatatan)
3. Pemerintah Provinsi, Kabupaten maupun Desa belum pernah memfasilitasi Perangkat Desa untuk melakukan studi banding penysusunan potensi desa/profil desa ke desa lain.

4. Pemerintah Provinsi, Kabupaten maupun Desa belum pernah melakukan pembinaan/ memberikan pelatihan/penataran/pengarahan kepada Perangkat Desa dalam penyusunan/pengisian format/daftar isian potensi desa/profil desa. Pembinaan yang dilakukan oleh Bagian Pemerintahan Desa Sekretris Daerah dan BPMPKB hanya sebatas pemanggilan kepada Perangkat Desa setiap 3 bulan sekali untuk mengevaluasi dan menanyakan permasalahan yang dihadapi Perangkat Desa dalam penyelesaian isian profil desa, sebab profil desa harus sudah selesai 3 bulan sebelum tahun anggaran baru.

5. Pemerintah Provinsi, maupun Kabupaten tidak membuat buku pedoman/panduan/ penyelasan penyusunan/pengisian format potensi desa/profil desa. Penyusunan profil desa sudah ada format baku, yaitu Lampiran II dan III Peraturan Menteri Dalam Negeri Nomor 12 tahun 2007)

6. Perangkat desa tidak pernah mendapatkan pembinaan/pengarahan dari Kabupaten/ kecamatan dalam penyusunan/pengisian daftar isian potensi desa/profil desa. pengarahan dari pemerintah kecamatan hanya batas waktu paling lambat penyerahan profil desa ke kecamatan.

7. Pemerintah Provinsi, Kabupaten maupun Desa belum mengalokasikan anggaran untuk pendataan potensi desa/profil desa.

8. Dana untuk pendataan potensi desa/profil desa belum ada, hanya sekedar honor untuk Perangkat Desa yang mengisi profil desa sebesar Rp.50.000,-/bulan selama 9 bulan dari BPMPKB.

9. Perhatian Pemerintah Kabupaten Kudus terhadap kesejahteraan Perangkat Desa relatif masih rendah, yaitu baru sebatas UMR bagi Kaur dan Kadus. Selama ini kesejahteraan Perangkat Desa diperoleh dari pengelolaan tanah bengkok, yaitu untuk masing-masing kepala urusan dan kepala dusun berpenghasilan 9.800.000,-/tahun, pembantu kaur kesara 4 orang dan pembantu kepala dusun 7 orang, pembantu Ladu 2 orang masing-masing berpenghasilan Rp. 4.900.000,-/tahun. Sedangkan untuk kepala urusan mendapat tambahan penghasilan masing-masing sebesar Rp.3.691.500,-. Untuk Sekretaris Desa karena sudah diangkat jadi PNS, mendapat tunjangan sebesar 13.400.000,-/tahun. Mulai tahun 2010 Ketua RW mendapat honor Rp.1.000.000,-/ tahun (dipotong pajak) dan RT sebesar Rp.700.000,-/tahun dari Pemda. 
10. Dalam rekruitmen Perangkat Desa penerapan persyaratan sudah dilakukan, namun demikian persyaratan diserahkan kepada desa masingmasing, seperti di Desa Getassrabi rekrutmen perengkat desa minimal berpendidikan SLTP, batas usia minimal 18 tahun dan maksimal 25 tahun, berbadan sehat. Sedangkan untuk pengisian Kadus dilakukan pemilihan langsung.

Permasalahan yang dihadapi BPMPKB sebagai instansi yang memiliki urusan untuk melakukan pembinaan dan fasilitasi terhadap pemerintahan desa untuk meningkatkan kemampuan Perangkat Desa dalam melakukan pendataan dan penyusunan potensi desa yang berhasil teridentifikasi adalah:

- fasilitasi Pemerintah Pusat dan Provinsi masih kurang

- belum adanya ketegasan Dirjen PMD Kemendagri terkait Nomenklatur PMD yang meliputi pemerintahan desa

- SOP tahun 2008 Kabupaten Kudus, terkait pembinaan terhadap pemerintahan desa PMD dan Pemerintahan Desa berdiri sendiri-sendir, sehingga dalam pelaksanaan pembinaan dan fasilitasi tidak sinergi

- anggaran yang terbatasnya, sehingga sulit untuk dialokasikan pada kegiatan pengumpulan data di desa

- adanya modul baru (Permendagri Nomor 12 Tahun 2007), tetapi belum ada pembekalan secara berjenjang dari Pusat

Permasalahan yang dihadapi Pemerintah Desa untuk meningkatkan kemampuan Perangkat Desa dalam melakukan pendataan dan penyusunan potensi desa yang berhasil teridentifikasi adalah

- pemerintah yang lebih atas kurang memperhatikan SDM (Perangkat Desa) untuk meningkatkan kemampuannya dalam melakukan pendataan profil desa

- fasilitasi Pemerintah Pusat sampai Kabupaten belum ada

- adanya keengganan Kepala Dusun dan RT untuk melakukan pendataan karena selalu mendapat pertanyaan dari warga, ada apa dilakukan pendataan, apa mau menerima bantuan

- $\quad$ penelitian dan pendataan potensi yang menjadi urusan pemerintah kabupaten belum diserahkan kepada pemerintah desa

- tugas pengisian profil desa tidak disertai dengan bantuan pembiayaan yang memadai

- belum ada pembekalan untuk mengisi modul baru profil desa (Permendagri Nomor 12 Tahun 2007).

\section{SIMPULAN}

Simpulan yang dapat disampaikan dari penelitian ini adalah: pertama, pengisian data-data profil potensi desa di desa sampel selama ini belum akurat dan tidak aktual, karena dalam pengisian profil desa belum sepenuhnya menggunakan sumber data dari BPS, Kecamatan, Kepala Dusun/RW, PLKB, Bidan Desa, Ketua RT dan masyarakat, tetapi cenderung menggunakan data tahun sebelumnya dan perkiraan.

Kedua, belum akurat dan aktual data potensi/profil desa di desa sampel disebabkan (1) Kepala Dusun, Ketua RW/RT selama ini belum melakukan pendataan/menginventalisir sumber daya desa; (2) sulitnya mendapat data dari masyarakat karena tingkat kesadaran/partisipasi masyarakat untuk melaporkan data-data bila terjadi perubahan masih rendah; (3) adanya keengganan Kepala Dusun dan Ketua RT untuk melakukan pendataan kepada masyarakat, karena adanya image dari masyarakat kalau ada pendataan selalu dikaitkan akan mendapat bantuan; (4) belum ada penyerahan urusan penelitian dan pendataan potensi desa dari pemerintah Kabupaten Kudus kepada Pemerintah Desa; (5) belum tersedianya dana untuk melakukan pengumpulan data; (6) terbatasnya sarana dan prasaran untuk melakukan pendataan; (7) randahnya kepercayaan terhadap data BPS, karena BPS memperoleh data dari Perangkat Desa; pengisian potensi/profil desa hanya ditangani 1 orang.

Ketiga, tingkat kemampuan Perangkat Desa dalam mengisi potensi/profil desa di desa sampel belum memadai, karena yang mengerjakan hanya 1 orang dan tidak dibekali dengan pendidikan dan pelatihan atau penataran pengumpulan data dan penyusunan profil desa; dan pengisian potensi/profil desa bukan menjadi tugas dan fungsi utama.

Keempat, pemerintah yang lebih atas kurang memperhatikan SDM (Perangkat Desa) untuk meningkatkan kemampuannya dalam melakukan pendataan profil desa, fasilitasi Pemerintah Pusat sampai Kabupaten belum ada, penelitian dan pendataan potensi yang menjadi urusan pemerintah kabupaten belum diserahkan kepada pemerintah desa, belum ada pembekalan untuk mengisi modul baru profil desa (Permendagri Nomor 12 Tahun 2007). Dengan demikian Pemerintah pusat maupun daerah belum melakukan upaya-upaya strategis untuk meningkatkan kemampuan Perangkat Desa dalam melakukan pendataan dan penyusunan potensi/profil desa. Hal ini tercermin dari:

\section{Rekomendasi}

Berdasarkan hasil dan pembahasan yang dilakukan, penulis merekomendasikan sebagai berikut: pertama, mengingat akurasi dan aktualitas data potensi/profil desa masih rendah, maka perlunya kebijakan standar penggunaan sumber data dalam pengisian profil desa. Dalam hal ini Dirjen PMD, hendakya memfasilitasi melalui surat edaran.

Kedua, kebijakan Pemerintah Kabupaten untuk secepatnya menyerahkan urusan yang menjadi kewenangannya kepada pemerintah desa sebagaimana diamanatkan Permendagri Nomor 30 
Tahun 2006, mengalokasikan anggaran yang jelas untuk pengisian potensi/profil desa. Dirjen PMD hendaknya mengavaluasi implementasi penyerahan urusan kabupaten/kota kepada desa.

Ketiga, kebijakan pengisian potensi/profil desa oleh tenaga pembantu teknis lapangan yang dibekali dengan diklat atau penataran terkait dengan penelitian dan pengumpalan data potensi/profil desa.

Keempat, Dirjen PMD, hendaknya memfasilitasi Pemda agar secara berjenjang memberi pembekalan Perangkat Desa dalam mengisi potensi/profil desa.

Kelima, Dirjen PMD, hendaknya mengevaluasi implementasi pengisian profil desa untuk menyederhanakan format Lampiran II dan Lampiran III Peraturan Menteri Dalam Negeri Nomor 12 Tahun 2007.

\section{DAFTAR PUSTAKA}

Buku:

Arikunto, Suharsimi. (2002), Prosedur Penelitian Suatu Pendekatan Praktek. Jakarta. Rineka Cipta.

Hasibuan, Melayu S.P. (2007), Manajemen Sumber Daya Manusia, Jakarta. Bumi Aksara, Cetakan Ke Sembilan.

Maarif, Syamsul (2003), Strategi Peningkatan Kompetensi A paratur Guna Mengantisipasi Kebutuhan Sek tor Pelayanan Publik (Orasi Ilmiah Wisuda XXII/ 2003 STIA LAN), Bandung.

Moleong, J Lexy.(2002), Metodologi Penelitian Kualitatif. Bandung. Remaja Rosydakarya,

Mustopadidjaja, 2002. Paradigma-Paradigma Pembangunan, Lembaga Administrasi Negara.

Notonatmodjo, Soekidjo. (1998), Pengembangan Sumber daya Manusia. Jakarta. Rineka Cipta.

Singarimbun, Masri (1989), Metode Penelitian Survey. Yogyakarta. Univertas Gajah Mada.

Supriatna, Tjahya., (2002), Manajemen Sumber Daya Aparatur Pemerintah Daerah (Pusat Kajian Pemerintahan STPDN), Fokus Media kerjasama dengan Pusat kajian Pemerintahan STPDN, Cetakan Pertama, Bandung.

Widjaja, HAW. (2003). Otonomi Desa. Jakarta: Raja Grafindo Persada.

\section{Makalah:}

Sanapiah, A. Aziz. (2010), Strategi Peningkatan Kompetensi Sumber Daya Manusia Aparatur Melalui Pendidikan dan Pelatihan.

Media:

http://ilmupemerintahan.wordpress.com/2009/04/05/tra nsformasi-tata-pemerintahan-desa/. Diakses pada tanggal 18 Mei 2012.

http://id.shvoong.com/social-sciences/1995189-potensidesa/\#ixzz1RCJXcpZk.Diakses pada tanggal 19 Mei 2011.

http://pasuruan.go.id/pemerintahan/.Diakses pada tanggal 22 Mei 2012.
Peraturan Perundang-Undangan:

Undang-undang Nomor 32 Tahun 2004 tentang Pemerintahan Daerah

Undang-undang Nomor 33 Tahun 2004 tentang Perimbangan Keuangan Pusat dan Daerah

Peraturan Pemerintah Republik Indonesia No 72 Tahun 2005 tentang Desa

Permandagri Nomor 30 Tahun 2006 tentang Tatacara Penyerahan Urusan Pemerintahan Kabupaten/Kota Kepada Desa

Permendagri Nomor 12 Tahun 2007 tentang Pedoman Penyusunan dan Pendayagunaan Data Profil Desa dan Kelurahan. 
